\title{
REFERENCES
}

WALKER, C. T., 1962. Separation techniques in sedimentary geochemistry illustrated by studies of boron. Nature, Lond., 94 (4833), 1073-1074.

1963. Size fractionation applied to geochemical studies of boron in sedimentary rocks. J. Sediment. Petrol., 33, 694-702.

PRICE, N. B., 1963. Departure curves for computing paleosalinity from boron in illites and shales. Bull. Amer. Ass. Petrol. Geol., 47, 833-841.

1964. Paleosalinity in the Upper Visean Yoredale Formation-Geochemical method for locating porosity. ibid., 48, 207-220.

\section{AGE OF THE ALPINE FOLDS OF SOUTHERN ENGLAND}

SIR,--In a recent letter Butcher (1963) considered that the presence of thick Tertiary strata north of the Brixton Anticline implies that this thickness together with the thickness of the missing part of the Cretaceous strata has been eroded away south of the steep limb. He suggested that with so much erosion on the south, yet even more Tertiary strata must have existed on the north side so that an equal degree of erosion could have taken place there. This avoids the idea of a steep-sided mountain of Tertiary strata, several thousand feet high. If, however, the folding was slow with erosion taking place simultaneously only over the axis this problem does not arise.

Butcher, however, states that the Alpine monoclinal folds could have been produced in less than one million years but there is much evidence that the

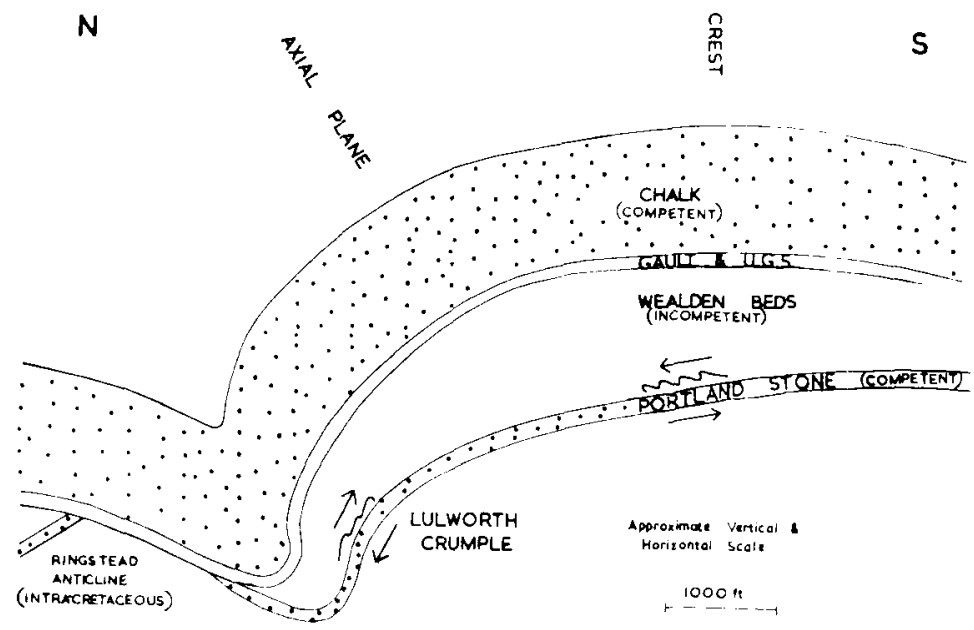

Alpine monoclinal folding of southern England occupied a considerable length of time with partial erosion of the folds taking place as they rose.

First east-west folding had been taking place in the Chalk of southern England before deposition of the Tertiary Beds. In Dorset, north of the Purbeck Monocline and the en échelon Chaldon-Poxwell-Ridgeway structures, which involved both monoclinal folding and faulting, the Tertiary Beds bear evidence of early Tertiary uplift and erosion of local structures. At East Lulworth and Morden the Reading Beds contain both flint pebbles and Upper Greensand chert (Reid, 1896) while the Bagshot Gravels at Morton and Black Down (Hardy's Monument) also contain Purbeck chert and limestone (Reid, 1896; Arkell, 1947). As Reid pointed out, westward overstepping of the Jurassic Beds by the Upper Greensand necessitates a local 
origin for these pebbles; further evidence for this is the occurrence of limestone as pebbles. Thus as implied by Reid (p. 494) the Chalk in the Weymouth area was locally uplifted and erosion took place to about 1,000 feet in Reading Beds times and considerably more during deposition of the Bagshot Beds.

At Creechbarrow north of the Purbeck Monocline, Arkell (1947, p. 240) noted that the large unrolled flints lying below the Creechbarrow limestone indicate local erosion of the Upper Chalk before deposition of the Bembridge Limestone. In Arkell's words, "Presumably this erosion can only be caused by the beginning of upheaval of the Purbeck Fold."

\section{REFERENCES}

ARkell, W. J., 1947. The Geology of Weymouth, Swanage, Corfe, and Lulworth. Mem. Geol. Surv. U.K.

Butcher, N. E., 1963. Age of the Alpine Folds of Southern England. Geol. Mag., vol. 100 , pp. $468-470$.

REID, C., 1896. The Eocene Deposits of Dorset. Quart. Journ. geol. Soc. Lond., 52, 490-6.

Department of Geology,

IAN M. WEST.

THE UNIVERSITY, SOUTHAMPTON.

\section{REVIEWS}

Principles of Paleoecology. An introduction to the study of how and where animals and plants lived in the past. By DEREK V. AGER. pp. xii +371 , illus. McGraw-Hill, New York. 1963. Price 83s. $6 \mathrm{~d}$.

This book illustrates in a revealing way the present state of " palaeoecology ". Dr. Ager has collected together a vast mass of information on non-systematic aspects of fossils. His summary of all this work, backed by a 27-page bibliography, will be valuable to many palaeontologists. The marine invertebrates, as the author admits, are covered much more thoroughly than the vertebrates or the plants. There is no great harm in that : probably it is for marine invertebrates that this kind of information has been most widely scattered and least easy to acquire. But even if the coverage had been more uniform, the book would still pose a fundamental question. What exactly is the nature of this science of "palaeoecology"? Surveying the range of topics covered by the book, it would seem to cover almost anything except straightforward systematics. For example, Dr. Ager includes studies of geographical distribution as " palaeoecology". No one would deny that distribution is governed in part by ecological factors ; but surely it is a recognized tenet of evolutionary biology that distribution cannot be explained wholly in terms of ecology. This is not an unimportant or artificial "boundary dispute" between two branches of science : it is fundamental to our understanding of the nature of ecology.

In his preface, Dr. Ager writes, " it seems to me far preferable to quote actual examples than to pursue abstract principles." The book indeed follows this aim faithfully, and will be found useful for reference precisely because it does concentrate on actual examples. But how is this to be reconciled with the expectations raised by the book's title ? For apart from a few introductory pages, the "principles" of palaeoecology are far from obvious. The primary division of the material is between "palaeoautecology" and " palaeosynecology", between the study of the ecology of individual fossil organisms and the study of the ecology of whole fossil communities. This is at least a useful division, if not an euphonious one ; but within each of these parts the logic of the arrangement seems to lie in the methods used, rather than in any principles. 